ざまな影響を受けているものの，同時にカメラの大企業の事例にみられるように大企業への成 長が中小企業からの重要部品の供給に支えられていた面もあると答えた。(2)関しては, 輸出 価格の持続的低下に対してカルテル活動を注じめさまざまな政策が試みられたが，功を奏せ ず，中小企業カルテルを展開するために業界の組織化が行われた側面が強く, 高度成長期の産 業政策として, 軽機械の場合, 中小企業近代化促進法も技術向上の面で一定の効果を上げた点 にも留意する必要があるとした。(3)については, 典型的な軽機械工業ほど石油危機後には存続 が難しくなり，過渡期としての1950・60年代の性格を物語っていると思われるとした。

続いて参加者から数多くの有益なコメントおよび質問が提出された。軽機械製品に関する技 術的な質問，ドイツとの比較史的観点からのコメントなどと並んで，4 報告の議論が軽機械製 品の価格と品質の問題に集中しており, デザイン・流行の問題をはじめとして, ある商品が有 望な輸出商品として成長していく上で大きな役割を果たす企業者にもっと注目すべきではない かといった重要な指摘もあった。

(さわい・みのる)

\title{
パネル報告 III
}

戦後日本における生産システムと産業地域

松島 茂

〈司会〉鈴木良隆 (一橋大学)

〈問題提起〉鈴木良隆 (一橋大学)

〈報告〉

1 多層的サプライヤー・システムの形成と企業家活動一一自動車産業における金属プレ ス部品の二次サプライヤーを中心に- : 松島 茂（法政大学）

2 戦後自動車部品取引における階層性の形成——ホンダにおける購買政策の部品単位取引 への移行を中心に一一：太田原準 (東邦学園大学)

3 中小企業の「成長」・分化過程と産業地域——東三河地域における機械工業の展開—— : 橋野知子 (神戸大学)

〈コメント〉橘川武郎（東京大学）

\section{問題提起}

戦後日本における「生産システム」と「産業地域」は，同一の中小企業を構成メンバーとし ながらも，これまで別個に研究されてきた。「生産システム」については，大企業を中核とし 
た精緻なまでの取引関係が強調されてきた。また「産業地域」については，「産業集積」の観 点から，地域内での横の取引関係や相互作用が明らかにされてきた。このパネルは，両者の関 係を立ち入って解明することによって，産業地域と取引関係の多様性やダイナミズムを論じよ うとするものである。対象としては，愛知県東三河地方を挟んで，隣接する浜松と西三河の 3 地域を，また分野としては自動車やオートバイなど輸送用機器の部品工業を取り上げる。

遅れて自動車産業に参入した日本の自動車メーカーは資本力にそしく, その生産システムを 模倣することはできなかった。その部品の多くをアセンブル工場の近隣に立地する中小企業を 含む多くの企業に外注せざるをえなかった。このような歴史的経緯から，日本の自動車産業の サプライヤー・システムは米国のそれとはかなり異質な構造を持つものとして発展してきた。

トヨタ，ホンダなどのアセンブルメーカーに部品を直接に納品している一次サプライヤーの多 くの二次サプライヤーから部品を調達し, さらに二次サプライヤーは近隣に立地する三次サプ ライヤーから部品調達, 加工外注を行うという形での多層的なサプライヤー・システムを形成 している。二次サプライヤー及び三次サプライヤーの大部分は，産業地域に近接して立地する 中小企業である。

報告 1 松島 茂「多層的サプライヤー・システムの形成と企業家活動一自動車産業におけ る金属プレス部品の二次サプライヤーを中心に一」」

報告者は自動車部品の中で中小企業が大きなウェイトを占める金属プレス部品に着目して, 2004年12月にトヨ夕系の一次サプライヤーであるフタバ産業及び豊田鉄工の二次サプライヤー 20 社に対する調査を行った。第 1 報告では，この調查に基づいて二次サプライヤーを中心に多 層的なサプライヤー・システムの形成過程，二次サプライヤーの機能についての分析結果が報 告された。

\section{(多層的サプライヤー・システムの形成)}

報告者の調查によれば，二次サプライヤーの創業の経緯は，刈谷市，岡崎市などの三河地域 で板金業，金属プレス業，金型製造業などの工場で働いて技術を修得した者が戦後の高度成長 期に創業したというケースが多い。これらの金属加工関連の小規模企業が，一次サプライヤー の生産規模の拡大に伴って逐次その多層的サプライヤー・システムの中の二次サプライヤーと して組み込まれて，中規模の企業に成長して行ったと解釈できる。この観点では，自動車産業 が生まれる以前からこれと技術的に関連する産業がこの地域に集積していて，この産業地域が インキュベーション機能を果たしたことが多層的サプライヤー・システムの形成に持つ意味は 大きいものがあると考えられる。

二次サプライヤーと三次サプライヤーの取引関係は，20社の中で相当のばらつきはあるもの の平均的には, 1 社当たり平均で継続的発注先が13.7社, スポット的発注先が 2.4 社, 両者を 合計すると16.1社の三次サプライヤーとの取引がある。特に，スポット的発注先が多い業種 
は，金型とプレス加工である。これ以外の業種では，ほとんどが継続的発注先である。これ は, 二次サプライヤーと三次サプライヤーの関係は継続的取引を基調としつつも, 受注数量の 繁閑の差を調整することが必要な業種においては，スポット的な取引を混合させることによっ て対応していると理解できる。二次サプライヤーは，近隣に立地する三次サプライヤーとの分 業を組み合わせながら一次サプライヤーの要求にこたえているのである。

20 社の納入先については，二次サプライヤーはその企業の成長過程で特定の一次サプライヤ 一との取引を拡大するとともに複数の一次サプライヤーへと取引先を拡大していく場合も多く 見受けられる。複数の取引先がある場合には，それらのすべてがトヨ夕系である場合が多い。 しかし，少数のケースではあるがトヨ夕系とホンダ系とが混ざる場合もある。その意味では， 多層的サプライヤー・システムは単純なカスケード型ではなくネットワーク型の要素が含まれ ている。

以上を総括すると，本報告で取り上げた一次サプライヤー 2 社は，1960年代の中ごろ以降に トヨ夕自動車の国内生産の急速な拡大に伴って, トヨ夕自動車との取引比率および取引高を拡 大していった。しかし両社が二次サプライヤーとの継続的取引関係を確立していった時期には 若干の違いがある。フタバ産業は，1950年代後半から1970年代中頃にかけて，すでに愛知県三 河地域に存在していた金属プレス加工及びこれに関連する技術を有する企業を巻き込むととも にさらに新しい企業の創業を誘発しつつ二次サプライヤーを堌やしていった。これに対して， 豊田鉄工は，1960年代後半から1980年代にかけて，同様に二次サプライヤーを増やしていっ た。このように多層的なサプライヤー・システムは, アプリオリにデザインされたものではな く, 完成車メーカーの国内で生産される車種の数及び生産台数の拡大に合わせて, 一次サプラ イヤー, 二次サプライヤー間の取引関係の再編を伴いながら，逐次的に形成されていったもの である。

\section{(二次サプライヤーの機能)}

多層的なサプライヤー・システムの中で二次サプライヤーは，以下の機能を果たしている。 第一に, 二次サプライヤーは, 複雑な形状の小物プレス部品であって自動化された設備に乗り にくい部品の生産を一次サプライヤーからの発注を受けて生産している。このような部品は多 品種であり, 生産ロットも様々である。第二に, 多品種で様々なロットの部品生産に即応した 生産を行うために近隣に立地する三次サプライヤーを活用して量的補完を行っているばかりに ではなく，二次サプライヤーの中には，一次サプライヤーと部品の開発過程に参加する企業も ある。これらの企業は, 形状のユニークなプレス部品について最終的に部品の設計図面が確定 する前の段階から開発に参画して，コストの安い生産方法が可能な設計について提案を行って いる。いわば，質的補完を行っているのである。この二つの機能を二次サプライヤーとしての 中小企業が併せ持つことが, 自動車産業の競争力を支えるものづくりパワーの源泉になってい る。 


\section{報告 2 太田原 準「戦後自動車部品取引における階層性の形成一ーホンダにおける購買政策 の部品単位取引への移行を中心に一」」}

第 2 報告では，本田技研工業（以下，ホンダと略）のサプライヤー・システムの形成過程 を, 部品取引の編成原理の変化に焦点を当てるかたちで報告された。加えて, ホンダが創業の 地とした浜松地域が，ホンダのサプライヤー・システムの形成に与えた影響についても，スズ キやヤマハのケースとの比較の上で言及された。

ホンダのサプライヤー・システムの形成を分析する際の焦点は，部品取引の編成原理が工程 単位調達から部品単位調達へと移行していく局面にあった。時期的に言うと設立（1948年）か ら1968年までの20年間である。ホンダは，創業期以来の工程単位調達による「arm's-length」 的な取引関係から，1968年の部品単位への全面的な調達方針の切り替えを宣言するに至るま で，段階的に一次サプライヤーを絞り込んだ。その結果，調達網の編成が大きく変化し，その 変化を一言でいうならば，単層性から多層性・階層性への移行であった。

ホンダの購買は, 創業期こそ市販品, 汎用品の調達が主であったが, 自主設計である D 型 ドリーム号の発売（1949年）を期に，自社設計による加工外注部品を数多く調達する必要が生 じてきた。ホンダは当初，浜松の金属機械加工業に部品加工を依存するが，金属機械加工業の 多くは一社一業であり，またホンダの交渉力も弱かったため，発注は，鋳造，切削，プレス， 研磨といった工程単位にならざるを得なかった。そして簡単な部品であっても, 複数の加工工 程を必要とするため, ホンダは部品の完成まで，その都度，仕掛品を自社便で運搬し，加工順 に取引先の加工業者を迴らなければならなかった。さらに，当時の取引先の加工水準では，ひ とつの加工が済むと，ホンダの資材課が逐一自社倉庫に戻して仕上がりをチェックし，手直し をしなければならなかった。

工程単位調達から部品単位調達への移行は，一足飛びに進んだわけではない。工程単位調達 による物流費，中間在庫の増大，管理業務の煩雑さなどは，量産規模の拡大に伴いホンダの喫 緊の合理化課題となって浮上したが，部品単位調達への移行には，加工業者の専業性や品質問 題の解消が求められた。ホンダは，1950年代から60年代を通じて，漸進的に検査体制や考課制 度を整備しながら，取引先の成長を待った。サプライヤー側でも，積極的に設備投資をおこな つて本業の前後工程に進出し, 部品単位で取引できる条件をつくっていく動きもみられた。

ホンダが全面的に工程単位調達から部品単位調達へと切り替える方針を表明したのは，1968 年である。部品単位調達とは, 従来の取引先の中から, 部品の原材料発注から完成までを責任 を持って管理統合する企業を選出して 1 次取引先とし，残りを 2 次以下とする編成原理の転換 であった。1 次層に残ることができた外注先は, 部品単位での品質責任と 2 次以下の QCD （品質，コスト，納期）管理の責任を負うことになった。

ホンダが工程単位調達から部品単位調達へと切り替えていく過程と同時に進行したのは, 「脱浜松」傾向であった。浜松に本社を置いた創業期のホン多は地場企業と系列的関係を組織 
しなかった。ホンダが本格的な取引先開拓を行ったのは, 東京へ本社を移し, 生産拠点を埼玉 に移した後である。取引先の選定基準は地縁や過去の実績よりも, 一定の QCD 能力と専門性 を重視し, 育成というよりは対等の関係が強調されたことから, 取引先の立地は東北から関 東, 中部, 北陸, 関西にいたるまで広く分散した。ホンダのこの特徴は, 浜松において織機・ 軍需時代からの取引先を「鈴木自動車協力組合」として組織し, 部品企業の系列化を進めたス ズキと特に対照的である。部品調達面からみた浜松地域の評価は慎重であるべきだろうという 含意をもつて報告を結んだ。

\section{報告 3 橋野知子「中小企業の「成長」・分化過程と産業地域——東三河地域における機械工 業の展開一」}

産業地域は, 起業や創業の温床としばしばいわれてきている。しかし, 産業地域の存在自体 がそこでの企業の成長や発展を保証するわけではない。第 3 報告では, 中小企業の「成長」の 論理を産業地域の形成・展開との関係から考察した。具体的には, 中小企業を取り巻く外的要 因を整理し, 経営戦略のあり方ならびに企業内部の成長要因に着目することによって, 産業地 域からさまざまなタイプの企業が成長してきたプロセスを検討した。ひとことで中小企業とい っても，あるいは，ス夕ート時は同じような規模の企業であったとしても，成長には多様な経 路があったこと, そしてそのような違いがもたらされた要因を検討し, 産業地域における中小 企業の成長の論理を考えることが, この報告の課題であった。

産業地域として対象としたのは, 愛知県東三河地域である。豊川市, 豊橋市, 蒲郡市, 新城 市の 4 市ならびに宝飯郡, 渥美郡を中心とした東三河地域では, もともと繊維産業が発達して いたことを受け，その関連産業が存在した。第二次大戦前においては豊川海軍工廠の開廠，戦 後は東側に隣接する浜松のオートバイ産業の発展に刺激されて, 機械工業が発達した。一方そ の西側には, トヨ夕自動車の生産システムを軸とした自動車産業が発達しており, 東三河地域 は地理的にトヨタやスズキといった二つの中心的産業の「はざま」に存在している。いわば, 東西の産業発展からの影響を強く受けることによって, 東三河の産業地域は形成されてきたと いってよい。そこで, 東三河の産業地域の発展を歴史的に跡づけつつ, 武蔵精密（豊橋市）な らびに永田鉄工（宝飯郡小坂井町）という二つの歯車専業メーカーのケース・スタディを通じ て，産業地域が中小企業の成長にどのような役割を果たしたのかを検討した。

創業者の技能形成のあり方は大きく異なったが, 両社は, 戦後の機械工業の需要増を受け て, ミシン, 農機具, 繊維機械, オートバイ, 自動車にかかわる部品加工を手がけながら成長 していった。武蔵精密は, ホンダの有力工場として国内 8 ・海外11力所の生産拠点を有するに いたっている。一方，永田鉄工はそのような拡大路線はとらず，輸送機器にフル・コミットす ることなくバラエティに富んだ生産を得意としている。両社とも企業の初期は小規模のいわば 「何でも屋」であったが, この報告では，これらが，(1)歯車専業メーカーとして中堅企業（中 
村秀一郎）と呼ばれるまでに成長した理由, (2)二社の成長の分岐点, 成長のあり方の違いを産 業地域との関係から議論した。

産業地域の外からの需要増は，この地域に存在した小規模の機械工業を成長させた。とりわ けオートバイや自動車といった成長産業にどのように対応するかは, 両社にとって大きな課題 であった。なぜなら, 需要に量的に対応することのみならず, 厳しい品質管理という質的な要 求もあったからである。これらのことは，経営者に設備投資や工場管理の重要性を認識させる こととなった（いわゆる機振法の申請書類を作成することも，長期的な企業経営という考え方 を浸透させるのに役だったという)。

興味深いことに，外部の拡大する需要への対応にはそれぞれに大きな違いがみられ，このこ とが両社のその後の成長のあり方を特徵づけることとなった。武蔵精密のように成長産業にフ ル・コミットし続けることは, 一方で需要の安定を, 他方で常に自らも拡大路線をとり続けな ければならないことを意味した。それとは対照的に，永田鉄工は，企業規模の拡大を一定のと ころに抑え，産業地域内の工程間分業のメリットを生かす戦略をとった。永田鉄工は，自動車 部品にむしろ特化しないことを選び, 多品種少量生産を強みとする専業メーカーへと転換して いった。

このような過程で産業地域が両企業に対して持った意味は，大変興味深い。企業の発生史的 には，産業地域は，工廠の開廠による機械工業の発達や浜松・豊田への隣接という同じ意味を 持った。一方で, 発展史的意味は両社にとって大きく異なった。武蔵精密は, 成長産業（ホン

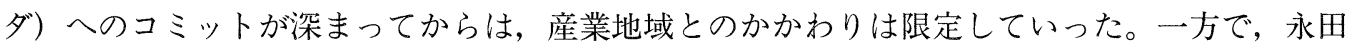
鉄工は多様な需要に応えるために地域内に外注先を確保し続ける必要があった。たとえば旋盤 加工の外注先については, 従業員のスピンアウトによる工場が多かったという。しかしなが ら, 戦前に工廠が設置されたものの地域内での関係が密に形成されなかったこのような産業地 域では，マーシャル的な意味での集積の外部性は限定的であり，成長産業へのコミットの仕方 が，みずからの成長のあり方を大きく規定していった。

\section{コメントおよび質疑応答}

以上の報告に対して, 橘川氏から，このパネルの特徴は，(1)「生産システム」面での垂直的 な取引関係と, (2)「産業地域」における水平的な取引関係を同時に検討する点にあるが, (1) (2)はどのように関連するのかというコメントがあった。また，松島報告に対しては，多層的サ プライヤー・システムはアセンブラー・一次サプライヤー・二次サプライヤー・三次サプライ ヤーのそれぞれにとってどのようなメリットをもたらすか，太田原報告に対しては，ホンダが 浜松で階層的取引関係を形成しなかったのはなぜか（スズキやヤマハが階層的取引関係を形成 できて, ホンダができなかったのはなぜか), 橋野報告に対しては, 武蔵精密と永田鉄工の成 長戦略の違いはどこから生まれたのかと質した。 
これに対して松島は，(1)は(2)の存在を前提として，アセンブラーの生産増大とともに(2)の再 編を伴いながら逐次的に形成されたのではないかと答えた。多層的サプライヤー・システム は，アセンブラーにとっては生産数量の変動に対する柔軟な対応を可能にする量的側面と新車 開発期間の短縮を可能にするという質的側面の両面におけるメリットが考えられる，またサプ ライヤーにとっては発注量の変動に対する柔軟な対応と自らは専門分野に特化しつつも分業に よって多様な発注に対応できるというメリットがあると答えた。

大田原氏は，コメントに正面から答えるだけの十分な資料の裏づけはそしいとしながらも， ホンダが後発かつ町工場からの出発であったことが, 実績や信用供与の点で地場サプライヤー との安定的な取引関係の構築を難しくしたのではないかと答えた。これに対して，スズキは織 機生産時代から核となる協力工場を擁し，それらに二輪車部品サプライヤ一への転換に必要な 設備，資金の支援を行うだけの資本力があったこと，ヤマ八も地元での高い信用度に加えてホ ンダが関東に移した後に浜松の北川製作所，昌和製作所を買収したことによって両社のサプラ イヤー群を利用することができた点をそれぞれが浜松で階層的取引関係を構築できた要因とし て指摘できるのではないかと述べた。

橋野氏は, 二輪車・自動車産業の成長以前はいわゆる「何でも屋」として特徴づけられる両 社ではあったが，例えば武蔵精密の企業史から次のようなことが推測されると答えた。すなわ ち, 成長する産業と関わってきた「経験」の有無である。武蔵精密には, 戦前は中島飛行機, 戦後はミシン産業という急速に成長した企業, 産業との取引があった。その過程では, 自らの 能力を超えるような要求に応えていかなければならないこともあったことは容易に想像され る。このような経験によって, さまざまな技術・スキル, 外部とのネットワークなどの経営資 源が「効率的」に蓄積され，このことが企業成長の鍵になることを知っていたのではないだろ うか。従って, 武蔵精密にとってはホン㚈フル・コミットして拡大路線をとることは, 一見 大きなジャンプに映るが，同社の企業史から見ると連続的であったと考えられる。これに対し て，永田鉄工は，1950年代半ばまでは武蔵精密とほぼ同規模であったが，それまでの経験の違 いが東三河地域内で再生産可能な方法，すなわち一社に傾倒せずバラエティに富んだ「品揃 え」で多数の取引先との関係を保持する戦略を選択させたと考えられる。

このほかにフロアーからは,「ホンダの急成長を考える場合, 前史としての東海精機時代の 技術や取引関係との関係性を考慮する必要があるのではないか。」，「日本の自動車部品サプラ イヤーの特徴を考える際に, 多層的取引関係の他に, 部品サプライヤーの開発力が高く, 製品 開発と関しても任されるという点がある。部品メーカーの開発力の形成と産業地域の関連につ いて，検討する必要があるのではないか。」,「取引先が地域的に分散しているか集中している かという問題を考察する際に, 部品納入に要する物流費の分担がどのように決まっているかに ついての情報が不可欠ではないのか。等のコメント及び質疑が行われた。 